\title{
Lactose: Use, measurement, and expression of results
}

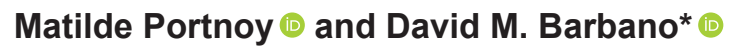 \\ Northeast Dairy Foods Research Center, Department of Food Science, Cornell University, Ithaca, NY 14853
}

\section{ABSTRACT}

Lactose has different uses in the dairy, food, and pharmaceutical industries. Being aware of the different forms of lactose and their concentrations can be very helpful in managing dairy product quality, properties, and manufacturing efficiency. Correct measurement and reporting of lactose concentration in milk and other dairy products will be of increased importance in the future as more value-added uses of lactose are developed and as milk lactose data are used in farm management decision making. Lactose should be reported as anhydrous lactose because lactose data will be used to make increasingly important decisions in dairy processing, dairy product labeling, and milk production in the future. Lactose also plays an important role in milk synthesis within a cow. Milk production factors and dairy cattle breed selection influence the amount of high value fat and protein produced per unit of lactose. If the off-farm value of lactose remains low, more attention may be focused on using ultrafiltration to process milk and leave 50 to $60 \%$ of the lactose and water from milk at the farm to recover the energy value of the lactose as feed and reduce the hauling cost of the high value components of milk to a dairy product manufacturing factory. Many methods exist to determine lactose concentration, but the most important methods are enzymatic assays, HPLC, and mid-infrared analysis. New, value-added uses for lactose need to be developed. Consistent and accurate methods of lactose measurement and consistent expression of lactose results will support this development process. Starting in January 2017, the USDA Federal Milk Market Laboratories began reporting lactose content of milk as anhydrous lactose and discontinued the reporting of lactose by difference.

Key words: anhydrous lactose, lactose monohydrate

Received April 13, 2020.

Accepted February 6, 2021

*Corresponding author: dmb37@cornell.edu

\section{INTRODUCTION}

Lactose is the main carbohydrate in milk at a concentration around $4.6 \%$ on an anhydrous basis (Lynch et al., 2007). This amount can change depending on factors such as the cow's stage of lactation (Auldist et al., 1995) or health (Auldist et al., 1995; Leitner et al., 2004). Pollott (2004) indicated that water moves into the mammary cell, where milk is synthesized, as an osmotic response to lactose concentration. Therefore, lactose is a key component in milk synthesis and secretion. Additionally, lactose is an important component in many dry dairy products and can have a large effect on the physical properties of milk powders and other dried dairy ingredients (e.g., hygroscopicity). Knowledge and understanding about the concentration of lactose in milk and dairy products is important for dairy herd management, milk production, and dairy processing. Important characteristics and information about lactose will be discussed, with an emphasis on the methods available for quantifying lactose, understanding the data obtained from these methods, and how these data can be applied to the dairy industry.

\section{LACTOSE: STRUCTURE, PROPERTIES, AND SOLUBILITY}

\section{Lactose and Lactose in Solution}

Lactose is a disaccharide composed of $\beta$-D-galactose and D-glucose (Campbell and Farrell, 2009). Lactose is a reducing sugar, and this influences many of its chemical interactions. (Fox, 1997; Fox, 2011). The D isomer of lactose is commonly found in nature. Lactose has 2 anomers: $\alpha$-lactose and $\beta$-lactose. Anomers are forms of the same carbohydrate molecule that arise when the monosaccharide ring opens and closes as a resonance structure. The difference between the 2 anomers is in the orientation of the hydroxyl $(\mathrm{OH})$ group that is bonded to the anomeric carbon (Campbell and Farrell, 2009). Each anomer produces different angles of change in optical rotation of polarized light when the light passes through a lactose solution. The $\alpha$ anomer, by definition, is the form with greater optical rotation in the dextro direction (Wong, 1988). 
The anomers can be distinguished from one another by polarimetry, where their specific rotations can be measured. The specific rotation for pure $\alpha$-lactose is $89.4^{\circ}$ and for $\beta$-lactose is $35.0^{\circ}$ (Fox et al., 2015). The lactose molecules in solution interchange between these 2 anomers in a temperature-dependent process called mutarotation. During mutarotation, the monosaccharide ring opens and closes, sometimes switching from one anomer to the other until an equilibrium is established at constant temperature. Once the equilibrium is established, meaning that the rate at which $\alpha$-lactose changes to $\beta$-lactose is the same as the rate at which $\beta$-lactose changes to $\alpha$-lactose, the proportions of these 2 at $20^{\circ} \mathrm{C}$ in solution are about $62.9 \% \beta$-lactose and $37.1 \%$-lactose (Jawad et al., 2014). Thus, $\beta$-D-lactose is more soluble in water at $20^{\circ} \mathrm{C}$ than $\alpha$-lactose. The equilibrium ratio of anomers changes as a function of temperature and at $>93.5^{\circ} \mathrm{C}$ the equilibrium is shifted to $100 \% \beta$-lactose (Haase and Nickerson, 1966; Whittier, 1944).

\section{Anomer Equilibrium in Solution, Mutarotation, and Solubility}

When $\alpha$-D-lactose monohydrate is added to water at $20^{\circ} \mathrm{C}$, an initial amount of it is dissolved until the solution is saturated with $\alpha$-lactose. This is the true solubility of $\alpha$-lactose. Then, as mutarotation takes place, some of the $\alpha$-lactose is converted into $\beta$-lactose, and the solution is no longer saturated with $\alpha$-lactose. Therefore, more of the $\alpha$-lactose dissolves until equilibrium between the 2 anomeric forms is reached. This would be the final total solubility of lactose at that temperature. If $\beta$-lactose were to be added to the $20^{\circ} \mathrm{C}$ solution, then the anomeric equilibrium would shift, creating more $\alpha$-lactose. However, because the solution is saturated with respect to $\alpha$-lactose, creating more of it would cause $\alpha$-lactose to crystallize out of the solution (Hudson 1904, 1908). The proportion of $\alpha$ to $\beta$ lactose in solution at given temperature can be measured by polarimetry. The rotation of the polarized light when it passes through the lactose sample or solution is measured and linked to the relative amounts of each anomer in the lactose solution or lactose crystals (Sharp and Doob, 1941; Jawad et al., 2012). Recently, an H-NMR method was used to measure the anomer proportion as well (Jawad et al., 2012).

This equilibrium ratio of the anomeric forms of lactose is dependent on temperature. As temperature increases, the equilibrium optical rotation decreases (Haase and Nickerson, 1966). This indicates an increase in relative percentage of $\beta$-lactose, because it has the smaller optical rotation of the 2 anomers. The equilibrium ratio of $\alpha$ to $\beta$-lactose can also be affected by changing the environment, for example, altering the solvent (Nickerson and Lim, 1974).

Unlike temperature, $\mathrm{pH}$ does not affect the equilibrium proportion of the 2 anomers, but it does affect the rate of mutarotation. The mutarotation rate is at its minimum at around $\mathrm{pH} 5$ and increases toward both directions of the $\mathrm{pH}$ scale. Mutarotation is fast at very low $\mathrm{pH}$ values but increases the most rapidly as $\mathrm{pH}$ increases (Troy and Sharp, 1930). Addition of sugars and salts can also affect the rate of mutarotation. The addition of salts to a lactose solution tends to accelerate the rate (Haase and Nickerson, 1966). On the other hand, addition of high concentrations of sucrose can decrease the rate of mutarotation, whereas small concentrations of sucrose only have a slight effect (Hunziker and Nissen, 1926; Patel and Nickerson, 1970). Factors that influence the rate of mutarotation can be important in drying processes where drying occurs very quickly and there may not be time for mutarotation to be complete, resulting in an unstable solid amorphous lactose glass in the powder.

Solvent alteration and addition of salts or sugars can also affect the total solubility of lactose in solution. The addition of certain calcium salts increases the solubility of lactose (Herrington, 1934). The addition of sucrose to a lactose solution reduces the solubility of lactose, especially when adding large amounts of sucrose (Nickerson and Moore, 1972). Therefore, adding sucrose to a saturated solution of lactose can cause lactose to crystallize out of solution. These relationships can be important in beverage formulation. Solubility can also be affected by altering the solvent. Solubility of lactose decreases with increasing concentration of some alcohols and with increasing alcohol chain length as well (Majd and Nickerson, 1976). In fact, alcohols such as ethanol and methanol have been used to extract lactose from dairy products such as skim milk, given that, by lowering the solubility of lactose with the addition of these alcohols, lactose crystallization is increased (Kyle and Henderson, 1970).

\section{Solid Forms of Lactose}

The main forms of solid lactose are $\alpha$-lactose monohydrate, anhydrous $\beta$-lactose, and amorphous lactose glass. The solid form of $\alpha$-lactose monohydrate forms when lactose is crystallized at temperatures $<93.5^{\circ} \mathrm{C}$ (Whittier, 1944). This is the reason why when measuring the solids content of milk by atmospheric oven drying that oven and sample temperature must be $>93.5^{\circ} \mathrm{C}$ at the instant when lactose starts to solidify to avoid formation of $\alpha$-lactose monohydrate and over estimation of solids content of milk and milk products (Clark et al., 1989). At temperatures $<93.5^{\circ} \mathrm{C}, \alpha$-lactose is 
less soluble than $\beta$-lactose in water and crystallizes out of solution (Hudson, 1908). As $\alpha$-lactose crystallizes out of solution, the concentration of this anomer in the solution decreases, and the equilibrium of the 2 anomers shifts and more $\alpha$-lactose is produced from $\beta$-lactose. This causes the solution to be saturated once again with $\alpha$-lactose, until it begins to crystallize out again (Zadow, 1984). Enough time must be allowed for mutarotation to occur and form more $\alpha$-lactose. This process continues, until the solution can is saturated with $\alpha$-lactose. The $\alpha$-lactose monohydrate form of crystallized lactose is hydrated with one molecule of water per molecule of lactose, contains $5 \%$ by weight water, and is the most common commercially found form of solid lactose in milk powders because it has the desirable property of being nonhygroscopic (Dincer, 2000).

Additionally, once $\alpha$-lactose monohydrate crystals are formed, 2 forms of anhydrous $\alpha$-lactose can be produced from it: unstable and stable anhydrous $\alpha$-lactose. Unstable anhydrous $\alpha$-lactose forms when $\alpha$-lactose monohydrate, once crystallized, is heated above $100^{\circ} \mathrm{C}$ under vacuum (Sharp, 1943; Dincer, 2000). This removes the water of crystallization. This form is very hygroscopic and forms $\alpha$-lactose monohydrate in the presence of water, without dissolving first (Dincer, 2000). Stable anhydrous $\alpha$-lactose forms when $\alpha$-lactose monohydrate crystals are heated at temperatures near $150^{\circ} \mathrm{C}$ in the presence of water vapor (Dincer, 2000). It is nonhygroscopic, very stable in solid form, and is very soluble in water (Sharp, 1943; Dincer, 2000).

Solid anhydrous $\beta$-lactose can be formed when lactose is crystallized from solution slowly at temperatures $>93.5^{\circ} \mathrm{C}$ (Whittier, 1944). This form of $\beta$-lactose does not contain water (Zadow, 1984), and has desirable characteristics in tableting for pharmaceutical applications (Nezbed, 1974) and a higher solubility in water than the $\alpha$-monohydrate form (Dincer, 2000). Additionally, anhydrous $\beta$-lactose is hygroscopic, very soluble in water, and has the highest melting point of the different crystallized forms of lactose (Dincer, 2000). It is also the sweetest crystallized form of lactose (Zadow, 1984)

Finally, amorphous lactose, also known as lactose glass, forms upon rapid drying of lactose, and contains a mixture of $\alpha$ and $\beta$-lactose anomers. Amorphous lactose glass is the major form of solid lactose produced when spray drying or freeze-drying milk and whey products (Zadow, 1984). Amorphous lactose glass forms when lactose dries so rapidly that it does not have enough time to form crystals (Whittier, 1944; Nezbed, 1974). Amorphous lactose glass is very hygroscopic and forms $\alpha$-lactose monohydrate crystals when moisture is absorbed from the air (Dincer, 2000; Haque and Roos, 2005) and causes caking of milk powders. It is desir- able for milk and whey powders to be nonhygroscopic, therefore an additional process called instantization is used at the end of commercial skim milk drying process in which moist hot air at $<93^{\circ} \mathrm{C}$ is passed through a fluidized bed of powder particles. The skim milk powder absorbs moisture from the hot air during instantization and the amorphous lactose glass at the surface of the powder particles forms nonhygroscopic $\alpha$-monohydrate crystals on the surface of powder particles and were shown in electron micrographs by Saito (1985).

\section{LACTOSE SYNTHESIS AND ROLE OF LACTOSE IN MILK SECRETION}

Lactose is the most abundant milk solid in bovine milk. A large amount of dietary energy and therefore dietary food energy is required for synthesis of lactose in mammals. Glucose and galactose are present in the cytosol of secretory cells and are transported into the golgi apparatus. Lactose is synthesized from glucose and galactose in the golgi apparatus of the milk secretory cells. Lactose synthesis is catalyzed by the enzyme lactose synthetase within the golgi apparatus, which is made up of 2 proteins: $\alpha$-lactalbumin and a galactosyl transferase (Linzell and Peaker, 1971).

Glucose is an important precursor for lactose synthesis (Hardwick et al., 1961). Holstein cows producing about $40 \mathrm{~kg}$ of milk/d secrete about 1,800 to $1,900 \mathrm{~g}$ of lactose/d. Thus, there is large demand for glucose in support of milk synthesis. When the immune system of a dairy cow is activated because of an immune system challenge (e.g., leaky gut, mastitis, viral infection) a large amount of blood glucose is used to support the immune system response. The glucose used to support the immune system response will not be available to support lactose synthesis and the milk output/cow per day will decrease (Kvidera et al., 2017; Liu et al., 2013). The concentration of lactose and soluble minerals drives the entry of water into the golgi apparatus from the cytosol of secretory cells to maintain osmotic equilibrium between the golgi apparatus, the cytosol of the secretory cells, and the blood stream (Pollott, 2004). Thus, the weight of milk produced/cow per day is tightly linked to the amount of lactose synthesized/ cow per day.

\section{LACTOSE IN DAIRY PRODUCTS AND BY-PRODUCTS}

The lactose content of dairy products varies greatly. Traditional fluid milks and conventional yogurts typically contain the full amount of lactose present in milk (as intact or hydrolyzed lactose), whereas cheeses, Greek-style yogurt, and other cultured dairy products may contain a reduced lactose content due to a whey 
drainage during manufacture. Whole milk, skim milk, buttermilk powder, and whole whey powders contain a large amount of lactose in a form that can be stored without refrigeration and transported long distances. During the manufacturing of milk and whey powders, lactose on the surface of the powder particles solidifies as in the form of amorphous lactose glass, which is hygroscopic. Amorphous lactose glass is formed because of the very rapid drying rate and temperatures $>93.5^{\circ} \mathrm{C}$. Instantization (Caric and Kalab, 1987; Fox et al., 2015) converts lactose glass to the more stable $\alpha$-lactose monohydrate, which is nonhygroscopic. This is done by exposing dried powder particles containing anhydrous lactose to moist hot air at temperatures below $93.5^{\circ} \mathrm{C}$. Exposure to moist hot air is done on a timing belt between the primary drying chamber and the external fluidized bed section of the dryer. Upon exposure and adsorption of moisture from the warm air the amorphous lactose forms nonhygroscopic $\alpha$-lactose monohydrate crystals. After the formation of the $\alpha$-lactose monohydrate crystals, the powder has a porous structure. The more porous structure produces a lower bulk density powder and improved dispersibility in water during reconstitution (Písecký, 1981; Caric and Kalab, 1987).

Lactose concentration and the solid form of lactose will influence the sensory properties of ice cream and cheddar cheese. With time of storage, lactose monohydrate crystals can form and increase in size in ice cream and be detectable on the tongue. This textural defect in ice cream is due to lactose crystallization and is called "sandiness" (Whitaker, 1933; Nickerson, 1956). Lactose crystallization in ice cream may be increased by moisture absorbing inclusions (e.g., dried fruits) or inhibited by addition of gums and stabilizers (Nickerson, 1960). A lactose-derived defect in cheddar cheese forms as a layer of calcium lactate crystals called white haze on the surface of colored cheddar cheese, which decreases consumer acceptance of the product (Agarwal et al., 2005; Dybing et al., 1988).

Increased consumption of cheeses has increased the supply of whey. To add value to whey, UF of whey has been done to produce value added whey protein concentrates (WPC) and whey protein isolates (WPI) (Maubois, 1980; Cheang and Zydney, 2004). The by-product of production of these whey protein products is UF permeate from whey that contains mostly lactose. At the same time, the popularity of reduced carbohydrate and lactose-free milks and beverages has increased in North America. Manufacture of carbohydrate-reduced fluid milks and milk protein concentrates and isolates from skim milk produces a milk permeate by-product that contains mostly lactose (Maubois, 1980; Tossavainen and Sahlstein, 2010). The US production of dry lactose powder in 1960 was 23 million $\mathrm{kg}$, and it has grown to 475 million kg in 2015 (International Dairy Foods Association, 2016). In 2019, about $68 \%$ of the lactose powder produced in the United States was exported (US Dairy Export Council, 2019). Differences in the ratio of lactose to fat and protein in milks produced by different breeds of cattle (e.g., Jersey milk has a lower amount of lactose per unit of fat plus protein than Holstein milk) may be of increasing importance in sustainability and feed resource utilization for commercial milk production. Research to maximize fat and protein production by dairy cows while minimizing lactose production or research to find more value-added uses of lactose from whey and milk processing is needed.

\section{COMMERCIAL PRODUCTION OF LACTOSE POWDERS}

Previously, commercial lactose was mainly produced from cheese whey and UF permeate from whey (Yang and Silva, 1995). More recently, UF permeate from milk has become a popular source of lactose. Both whey and milk permeate contain very little protein and high lactose content and can be further processed by reverse osmosis or nanofiltration to obtain higher concentrations of lactose (Atra et al., 2005). The next steps for the production of lactose are the following: concentration, usually by evaporation; crystallization, which can be spontaneous or by seeding with a small amount of $\alpha$-lactose monohydrate (which is the most commonly commercially produced); separation of crystals from mother liquor, which is done by centrifugation; washing; drying; and, finally, classification. This crude lactose can be refined to produce pharmaceutical-grade lactose (Kastens and Baldauski, 1952; Westhoff et al., 2000). A lot of the lactose produced in the United States is exported in the form of dried permeate to other countries for animal feed purposes.

\section{COMMERCIAL USES OF LACTOSE}

\section{Infant Formula}

Apart from including pure lactose in infant formula, lactose is also used in the production of galacto-oligosaccharides (GOS) for possible addition to infant formula to make it more like human milk. The GOS are produced by an enzymatic processing of lactose (de Roode et al., 2003; Torres et al., 2010). Many of these GOS are found in human milk (but rarely in bovine milk) and are being considered for addition to infant formula because of their anti-inflammatory properties in the lower gut and their prebiotic properties that may be beneficial to infants. (Boehm et al., 2003, 2005) 


\section{Pharmaceuticals}

$\beta$-Lactose anhydrous, $\alpha$-lactose monohydrate, and amorphous lactose are all used in the pharmaceutical industry for tablet making (Gunsel and Lachman, 1963). The chosen form of lactose depends on the properties desired for the powder. Lactose is also used in the production of spray-dry powder inhalers, where it acts as a carrier for low concentration active ingredients. For this, $\alpha$-lactose monohydrate can be sieved to produce different and desired particle sizes (Kaialy et al., 2012).

\section{Animal Feed}

Dried UF permeate or high-lactose liquids can be mixed with other nutrients (e.g., lactose, nitrogen-containing compounds) to produce a low-cost animal feed (Zadow, 1984; Yang and Silva, 1995). For example, after cheese production, incorporating cheese whey in cows' diets can be a solution to environmental issues that are involved in disposing of whey by-products. When liquid cheese whey is used properly as a substitute for some of the water consumed by lactating cows, milk yield, protein content, and fat content are unaffected. Body weight, reproduction performance, mammary health, and rumen activity are also consistent with those of cows on regular hay or silage diets consuming no liquid whey (Palmieri et al., 2017).

Additionally, feeding lactose in the forms of fresh liquid whey or pure lactose seems to increase ruminal butyrate and plasma BHB levels, but does not seem to reach levels where cows are at a higher risk of developing ketosis (DeFrain et al., 2004). Incorporating lactose in dairy cattle rations does not seem to affect milk protein content as long as sufficient metabolizable nitrogen is available to support desirable microbial growth in the rumen resulting in an increase in microbial biomass. Added lactose can also improve nutrient use, because there is evidence that it can decrease milk urea nitrogen concentration (DeFrain et al., 2004). Feeding lactose can improve the absorptive capacity of the rumen, decrease liver lipid concentrations, and slightly increase DMI, as cows on a high-lactose diet do not seem to experience the expected decrease in DMI 3 weeks before calving (DeFrain et al., 2006).

\section{ANALYTICAL METHODS FOR LACTOSE MEASUREMENT}

For management of lactose utilization, understanding lactose production at the cow level, and finding new uses for lactose, it is important to have analytical methods to quantify lactose and a consistent method of expression of the concentration of lactose in milk and milk products. There is need for lactose measurement for control of lactose fractionation during processing, measurement of lactose in animal feeds for correct calculation of dietary energy content, measurement of lactose output/cow per day in managing energy balance in dairy cows, nutritional labeling of food products, and for regulatory purposes when label claims are made about the lactose content of a food product. The method of expression and determination of lactose has not always been defined clearly and sometimes lactose content has been expressed as anhydrous lactose, lactose monohydrate, or simply a lactose value calculated by the difference between milk total solids minus (fat + protein + an ash factor). However, those data report it as lactose without specifying anhydrous lactose, lactose monohydrate, or lactose by difference. This has caused inconsistency of reported lactose values for milk and milk products. The possible analytical methods for lactose measurement are summarized below.

\section{Polarimetry}

The specific rotation of a molecule is the rotation in degrees observed upon passing polarized light through a path length of $1 \mathrm{dm}$ at a concentration of $1 \mathrm{~g} / \mathrm{mL}$. For reporting purposes, the specific rotation is usually accompanied by the wavelength (often the D line of sodium, $589 \mathrm{~nm}$ ) and the temperature: $[\alpha]_{\kappa}{ }^{\mathrm{T}}$, where $\mathrm{T}$ is the temperature at which the measurement was taken, and $K$ is the wavelength that was used. For example, for $[\alpha]_{\mathrm{D}}{ }^{25}$ the measurement was performed at $25^{\circ} \mathrm{C}$ and the wavelength used was the $\mathrm{D}$ line $(589 \mathrm{~nm})$ of the sodium spectrum.

Polarimetry is a very old method of measurement of concentration of compounds. Polarimetry (AOAC International, 2016, method 896.01) is the classical approach for measurement of lactose, but it is difficult to execute and uses toxic reagents that create waste disposal and safety issues. The AOAC International polarimetry method has remained unchanged since 1896. Specific rotation of a compound can be related to the concentration of a chiral compound in a sample (Polavarapu, 2002). To convert an observed rotation to specific rotation, the observed rotation is divided by the concentration in $\mathrm{g} / \mathrm{mL}$ and the path length in decimeters. The equation is as follows: $[\alpha]=\frac{\alpha_{0}}{c \cdot l}$, where $[\alpha]$ is the specific rotation in degrees, $\alpha_{0}$ is the observed rotation in degrees, $\mathrm{c}$ is the concentration in $\mathrm{g} / \mathrm{mL}$, and $\mathrm{l}$ is the path length in $\mathrm{dm}$.

Lactose has asymmetric carbon centers, giving it chirality, and making it optically active. The known specific rotation for lactose in solution at equilibrium is about $50.6^{\circ}$ at $25^{\circ} \mathrm{C}$ using the sodium D line (Jawad et 
al., 2012). Polarimetry can be used to determine lactose concentration using the optical rotation measured from a sample (Abbott and Stiles, 1965). This is a primary research method. However, it is not specific to lactose because other compounds that are optically active in the sample being studied can influence the rotation measurement. It is not used often to quantify lactose, because there are newer and better methods, such as enzymatic methods and HPLC. However, to determine the anomer composition of lactose, polarimetry remains a widely used method.

\section{Reducing Sugar Method}

Reducing sugar methods are based on lactose's ability to oxidize easily and reduce another compound. The reducing sugar methods are colorimetric methods that involve lactose reacting with a reagent to form a colored compound. An example of this is Dreywood's reagent (Dreywood, 1946; Morris, 1948). Absorbance can then be measured using instruments as simple as a visual colorimeter or a spectrophotometer to determine lactose concentration based on Beer's Law, where the concentration of the colored compound that is formed is proportional to the concentration of lactose that was present in the sample. Lactose in samples that contain mixtures of sucrose and lactose can be studied as well with these methods (Perry and Doan, 1949). Another example of a reducing sugar method uses Fehling's solution (Munson and Walker, 1906). This method is based on the combination of 2 separate solutions to form a powerful oxidizing agent that can react with reducing sugars (e.g., lactose), and results in a copper oxide precipitate. The Munson and Walker method (Munson and Walker, 1906; AOAC International, 2016, method 930.28) uses a classic gravimetric approach to quantify the copper oxide formed. However, there is also a volumetric approach (Scales, 1915), and a potentiometric approach (Seoane et al., 2008). Both colorimetric and Fehling's solution are secondary methods, because they require calibration standards. They are not specific to lactose because the redox reactions that they are based on rely on the presence of a reducing species, which could be many chemical compounds other than lactose, such as other monosaccharides, maltose, or inverted sugar. These methods, similarly to polarimetry, were developed before enzymatic methods or HPLC instruments were available. Therefore, with the newer, faster, and more efficient methods, these older reducing sugar methods are not used often. Both the properties of optical activity and reductive activity are not exclusive to lactose. This reduces the specificity for lactose of the methods based on these properties.

\section{Enzymatic Methods}

There are 2 main detection methods used in combination with enzymatic assays for lactose: spectrophotometric and differential pH. For the spectrophotometric method, the milk samples must be clarified (i.e., removal of fat and protein) before the step of enzymatic analysis, because any turbidity or particulate matter could interfere with the absorbance reading due to light scattering. The precipitation of fat and protein is typically done using Carrez solution or a low concentration of trichloroacetic acid (Lynch et al., 2007). AOAC International (2016) method 2006.06 determination of the lactose content of milk was a replacement for the previous AOAC International (2016) method 984.15 with improved within- and between-method performance. The first step in the spectrophotometric enzymatic assay is the hydrolysis of lactose into D-glucose and D-galactose, by the enzyme $\beta$-galactosidase at a $\mathrm{pH}$ of 6.6 . Next, the enzyme $\beta$-galactose dehydrogenase, at a $\mathrm{pH}$ of 8.6 , oxidizes the D-galactose to Dgalactonic acid, whereas $\mathrm{NAD}^{+}$is reduced to reduced $\mathrm{NADH}$. The NADH absorbs radiation at $340 \mathrm{~nm}$, and the formation of NADH is stoichiometrically related to the concentration of lactose present. Therefore, using Beer's Law, the concentration of lactose can be determined based on change in the absorbance of the NADH (Kleyn, 1985; Lynch et al., 2007). No standard curve with lactose reference material is needed because the extinction coefficient of NADH is known. The results for lactose can be expressed as either lactose monohydrate or anhydrous lactose by calculation (AOAC International, 2016, method 2006.06), but the method of expression needs to be reported with the result. There are similar spectrophotometric enzymatic lactose methods published by the International Dairy Federation (IDF), such as IDF (2002a) method 79-1 for dried milk, dried ice cream mix and processed cheese using enzymatic detection of glucose and IDF (2002b) method 79-2 for the same products but using enzymatic detection of galactose to quantify lactose in those products.

For the differential $\mathrm{pH}$ method, the milk samples do not need to be clarified before analysis. The first step in the enzymatic assay of lactose with this method is the same as in the spectrometric method, where lactose is hydrolyzed into D-glucose and D-galactose by $\beta$-galactosidase. Then, a hexokinase causes D-glucose to react with ATP to form D-glucose-6-P, ADP, and a proton $\left(\mathrm{H}^{+}\right)$. The production of protons changes the $\mathrm{pH}$ of the solution. Therefore, with the change in $\mathrm{pH}$, the concentration of $\mathrm{H}^{+}$produced can be determined, with which the concentration of D-glucose that was formed can be calculated and is stoichiometric to the amount 
of lactose that was present in the sample. The change in milli-pH is directly related to the concentration of lactose using a pure lactose standard (Luzzana et al., 2001, 2003), as described in IDF standard number 214 (IDF, 2010).

Enzymatic methods are very specific to lactose. The enzymatic spectrophotometric method is a primary method, and its specificity relies only on the accuracy of the extinction coefficient for NADH that is used in the calculations. No reference standard is used to calculate the result. On the other hand, the enzymatic differential $\mathrm{pH}$ method is a secondary method, because it requires calibration with a high purity lactose reference standard. The spectrophotometric method requires that the milk samples be clarified before the analysis, and the differential $\mathrm{pH}$ method does not require this sample preparation.

Amamcharla and Metzger (2011) described the use of a blood glucose meter to measure the lactose content of milk by first carrying out a sample preparation step with an enzyme reaction to hydrolyze lactose into glucose and galactose, then use the blood glucose meter to measure glucose and calculate lactose content of milk. This method would be rapid and low in equipment cost for a rapid screening method to estimate lactose content of milk.

\section{HPLC}

High-performance liquid chromatography involves separation, identification, and quantification of lactose in a sample, using pressure to force solvent through a closed column that contains fine particles. Based on interaction of lactose with the mobile phase (solvent) and stationary phase (column particle materials), lactose can be separated from other sugars because different sugars elute from the column at different times (Harris, 2010). For the determination of lactose, an internal standard and lactose are separated by a cation exchange column and detected by a differential refractometer detector (IDF standard 198, IDF, 2007). The HPLC detector technology has advanced (e.g., evaporative light scattering, electrochemical, pulsed amperometric detectors are now available) but have not yet been added to official methods because interlaboratory studies and method performance validation are required for revision of official methods. It is typical for official methods to lag behind cutting edge analytical advancements.

The HPLC is a secondary method, because it relies on calibration with high purity lactose calibration standards. However, HPLC is very specific to lactose. This method has very good differentiation among carbohydrates, unlike the reducing sugar methods. The HPLC instruments are more expensive and require a more highly trained technician than spectrophotometric methods.

\section{Very Low Lactose Products}

Based on consumer preferences many companies have developed low or lactose-free versions of many dairy product and milk-based beverages. There are label claims of certain percentage of lactose reduction, or even lactose-free claims on dairy product labels. Lactose-reduced dairy products can be made by 2 different approaches: (1) enzymatic hydrolysis of the lactose with added lactase or fermentation of the lactose with a culture; or (2) the physical removal of all or a portion of the lactose by filtration technology or milk coagulation, washing a curd, and removal of whey. For beverages, lactose removal by ultrafiltration, hydrolysis of lactose using lactase, or a combination of the 2 technologies are the common methods to produce beverages with $70 \%$ lactose reduction to beverages with label claims of being lactose-free. Verification of the label claims and inproduction process control present some new analytical challenges in lactose analysis. In general, the enzymatic methods were designed for a milk-product based sample matrix that contained a moderate to high concentration of lactose. Generally, official methods for lactose analysis were validated for that type of sample matrix and analyte concentration. Thus, the new low-lactose and lactose-free products are new analytical challenges. The HPLC methods probably are the easiest to adapt to lower concentrations of analyte (i.e., lactose), and the main issue would be the limit of detection for lactose. This is where new detector technology versus RI detectors could be a big advantage, and studies of these on low-lactose and lactose-free dairy products are needed. The optimization of the enzymatic methods for very low lactose levels are a bit more challenging, particularly in lactose-free dairy products that have been produced by hydrolysis of the lactose into glucose and galactose. However, recently one of the lactose enzymatic method kit manufacturers (Megazyme) has received AOAC International approval for a new enzymatic lactose kit for analysis of low-lactose products (AOAC International, 2019). The method involves 2 key steps, namely sample clarification and enzymatic removal of free glucose, followed by spectrophotometric measurement of remaining glucose in the sample before and after incubation with a specific $\beta$-galactosidase. Lactose in the sample is then calculated.

\section{Mid-Infrared Milk Analysis}

The mid-infrared (MIR) method is based on measuring absorbance of characteristic vibrational modes 
in the lactose molecule. Vibrational modes of interest for lactose are those of the $\mathrm{OH}$ groups AOAC International, 2016; method 972.16). However, lactose is not the only compound in milk with $\mathrm{OH}$ groups, so corrections must be made for background absorbance by other compounds. Also, because water (the primary constituent of milk) absorbs MIR light very intensely, background corrections must be made for variation in water concentration from sample-to-sample (Lynch et al., 2006).

There are 3 different approaches for the estimation of a component concentration in a milk sample: (1) optical filters, where physical filters are used to obtain the wavelength and bandwidth of interest (Goulden, 1964); (2) virtual filters, where Fourier-transform infrared spectroscopy is used to obtain a full spectrum, and from there, the wavelengths and bandwidths can be virtually selected from the spectrum (Kaylegian et al., 2009); and (3) partial least squares models using data from many wavelengths throughout the MIR spectrum. The wavelengths for the virtual filters used for the analysis of lactose on an infrared instrument are $9.542 \mu \mathrm{m}\left(1,048 \mathrm{~cm}^{-1}\right)$ as the sample wavelength, with a bandwidth of $0.092 \mu \mathrm{m}\left(20 \mathrm{~cm}^{-1}\right)$, and a reference wavelength of $7.734 \mu \mathrm{m}\left(1,293 \mathrm{~cm}^{-1}\right)$ with a bandwidth of $0.084 \mu \mathrm{m}\left(14 \mathrm{~cm}^{-1}\right)$ (Kaylegian et al., 2009). Intercorrection factors to compensate for the background variation of fat, protein, and water concentration are determined and used in the calculation of lactose concentration (Barbano and Clark, 1989; Lynch et al., 2006). The MIR method requires the use of calibration samples with known lactose reference values to calibrate (i.e., adjust slope and intercept of the intercorrected predicted value) the instrument and be able to quantify lactose in milk samples (Barbano and Clark, 1989; Lynch et al., 2006). The units of expression of the form of lactose will result in different reference values (i.e., lactose monohydrate, anhydrous lactose, or lactose by difference) in $\mathrm{g} / 100 \mathrm{~g}$ of milk for the same milk sample, so clearly stating the form of lactose reported should always be included with the results. For example, a milk that contains $4.6 \mathrm{~g}$ of anhydrous lactose/100 $\mathrm{g}$ of milk will contain $4.84 \mathrm{~g}$ of lactose monohydrate/100 g of milk, because lactose monohydrate is $5 \%$ by weight water.

The MIR has very low specificity to lactose, because many other compounds in milk can contribute to the absorbance at the wavelengths where lactose is determined, so appropriate corrections must be made (Lynch et al., 2006). However, for routine milk analysis, MIR is often the chosen method because of its high speed and low cost. Its low specificity for lactose can be overcome by the fact that milk does not contain other sugars. However, for a product such as ice cream, where sucrose concentrations are high, the infrared results could be affected by the absorbance of this sugar instead of lactose. The MIR can be used to rapidly run large numbers of samples directly with no chemical reagents. However, it's important to remember that the measurements rely on an accurate chemical reference method and an appropriate calibration.

\section{Calculation and Expression of Lactose Results}

Lactose data can be reported as anhydrous lactose $(342.30 \mathrm{~g} / \mathrm{mol})$ or lactose monohydrate $(360.31 \mathrm{~g} / \mathrm{mol})$. It is essential to know which is being measured and how it is being reported. Normally, the dry powdered lactose reference material purchased is lactose monohydrate. This is common because lactose monohydrate can be prepared in high purity, is stable and nonhygroscopic, and can be stored without absorption of moisture from the air. Unfortunately, analysts sometimes forget that this material is only $95 \%$ by weight lactose when they calculate their standard curves for an analytical method and then report the results as lactose. Thus, it has been common, particularly in published studies of milk composition, to see differences in mean lactose concentration from study to study on the order of $5 \%$ relative. Therefore, when reporting values for lactose, it should always be made clear if lactose is being expressed as anhydrous lactose or lactose monohydrate.

The other point of confusion is when data are reported indicating that the values are lactose, when a residual lactose calculated by difference was reported (which also overestimates lactose by varying degree). Lactose by difference is calculated by subtracting protein, fat, and ash from the TS content (Abbott and Stiles, 1965). However, there is no assurance that the result of this calculation reflects the actual lactose content of the milk samples. The result obtained also depends on whether, in the total solids calculation, the protein was determined using total nitrogen or true protein (Barbano et al., 1990, 1991). Additionally, depending on how the drying to obtain the solids measurement was done, lactose anhydrous or monohydrate could be present in the solids (this depends on what temperature the oven was at when lactose began to crystallize). Lactose by difference also has the drawback that, to obtain the results, 4 separate components must be determined (protein, fat, ash, and total solids), and the uncertainty of each measurement is propagated throughout and affects the final lactose result (Lynch et al., 2007). Also, there are other nonlactose compounds included in the calculation by difference. Given the availability of methods to specifically measure lactose content of milk and dairy 
products today, use of lactose by difference data should be discontinued. The USDA Federal Milk Markets discontinued reporting lactose by difference and started using AOAC International method 2006.06 (Lynch et al., 2007) routinely for measurement and reporting anhydrous lactose content of milk starting January 2017. The within and between laboratory performance of AOAC International method 2006.06 in the USDA laboratories was reported by Wojciechowki et al., 2016.

\section{USE OF LACTOSE DATA}

\section{Fluid Milk and Beverages}

Lactose-reduced or lactose-free dairy products can be made by removal of lactose by filtration, hydrolysis of lactose, or combination of the 2 approaches, and all of these are being used today. Measurement of lactose and lactose hydrolysis products (i.e., glucose and galactose) in low-lactose products is important for lactose-intolerant consumers (van Scheppingen et al., 2017). This is particularly important in lactose-reduced and lactosefree milks and dairy-based beverages. Low-lactose beverages can be a challenge for analytical methods because a low limit of detection is needed. Also, the ability to differentiate among concentrations of lactose, glucose, and galactose may be required.

\section{Dried Milk and Whey Products}

Dried milk and whey products are important products both domestically and internationally, and there are composition standards for these products that usually specify the protein as a percent of TS in the product. The primary milk component of high value in these dried products is protein, but most of the remaining milk solids in these products is lactose. Thus, control of both protein and lactose content of these products is critical for both economic performance of the processor, and consistency of functionality and nutrition profile of the dried milk ingredient. In the production of WPC, WPI, milk protein concentrates, and milk protein isolates, lactose is removed by UF. Therefore, control of protein to anhydrous lactose ratio of the liquid product during processing before drying is important. If lactose content is too low, the protein concentration could be too high; this could result in an economic loss for the processor if the product is sold based on a minimum protein content, and no premium is paid if the protein content exceeds the minimum. If lactose content is high, the protein could be too low and may not meet the product minimum protein standards (American Dairy Products Institute, 2014) and may be rejected by the customer.

\section{Cultured Products}

In the last 40 years in the United States, production and consumption of cheese have increased greatly (International Dairy Foods Association, 2016). At the retail level, yogurt consumption and the variety of cultured products has also increased greatly. Large quantities of cheese are used in food service in the United States, and precise control of composition to achieve refrigerated shelf-life for distribution and proper functionality when cheese is used as an ingredient has increased in importance. Lactose is the main substrate for fermentation and production of lactic acid in cheese making. Therefore, controlling the concentration of lactose in the milk used for cheese making can be used to control the degree of acidity and browning properties of cheeses (Moynihan et al., 2016). Limiting lactose concentration can stop the culture and its fermentation process at a desired $\mathrm{pH}$ level, prolong shelf-life, and even prevent unwanted fermentations by other microbes in the product.

\section{Milk Production and Dairy Cattle Management}

Lactose is the milk solid component in the highest concentration in milk, but of the 3 main milk components (fat, protein, and lactose) it has the lowest commercial value per unit weight. As a result of the low value of lactose, not much attention has been focused on the quality of lactose data provided by payment and dairy herd improvement laboratories. As milk production has increased, the commercial supply of lactose has increased. The challenge has been to find economically viable uses for lactose, particularly when lactose is a by-product of cheese and high protein milk and whey powder manufacture. Therefore, the industry needs to focus more on maximizing the amount of high value milk components (i.e., fat and protein) produced per unit of lactose produced by dairy cows. Feed energy input is required for dairy cows to produce lactose and directing more energy to fat and protein production and less energy for lactose production in the current situation of lactose utilization and supply would be prudent. Different breeds of cattle have different ratios of fat + protein to lactose and this may be an opportunity to improve sustainability of milk production and economic viability if the milk pricing system sends the appropriate economic signals related to differences in economic value of these milk components. Today's management of dairy cattle nutrition and the economies of scale achieved by larger farms have increased the focus on dairy cattle nutrition management and strived to maximize the productivity and economic return in milk production. Therefore, there is increased impor- 
tance in knowing the energy output in milk/cow per day and having correct lactose data will be of increased importance to correctly balance energy input as feed and energy output as milk. The concept of removing a portion (50-60\%) of the water and lactose at some large farms by UF (and not hauling it to a dairy plant), and proper utilization of lactose as a fermentable carbohydrate source in dairy cattle feeding is of interest.

As precision dairy farm management tools continue to evolve, more sophisticated milk analysis tools may be integrated into on-farm milking systems to better manage health, reproduction, and net revenue produced by cows to maintain economic sustainability of milk production. Accurate lactose data, in combination with other milk analysis metrics, may aid in monitoring cow udder health because lactose content of milk decreases when cows have mastitis. Recent studies (Forsbäck et al., 2010; Berglund et al., 2017) reported a correlation between lactose content and SCC in milk. As SCC increased, lactose content decreased. Lactose data can also be used to monitor issues with milk yield. Lactose is the major osmotic component in milk (Linzell and Peaker, 1971; Davis et al., 1999). Therefore, there is a strong correlation between lactose production $(\mathrm{g} / \mathrm{cow}$ per day) and milk yield, because of the role lactose plays as an osmotic regulator in milk production. As milk lactose yield increases, milk yield increases (Pollott, 2004; Miglior et al., 2007). However, factors in dairy cattle health (i.e., mastitis, laminitis, leaky gut) cause an immune response resulting in an increased demand for glucose for higher priority metabolic functions than for milk lactose production. As a result, both milk lactose and milk production/cow per day will decrease. Knowing the change in anhydrous lactose output from a cow in grams/day helps identify the magnitude of energy demand that has been created to support the immune response or other metabolic activities in the lactating dairy cow that have higher metabolic priority for utilization of glucose than synthesis of lactose. The variation in lactose concentration and output per day along with a range of other milk analysis metrics may become more important in diagnostic trouble shooting of animal health issues.

\section{CONCLUSIONS}

Lactose has different uses in the dairy industry, and the understanding and application of lactose data can play an important role. Being aware of the different forms of lactose and their concentrations can be very helpful in managing dairy product quality and properties. Correct measurement of total lactose content of milk will be important for evaluation of milk production efficiency, dairy herd management for milk produc- tion, and cow health. Lactose should be reported as anhydrous lactose because lactose data will be used to make increasingly important decisions in dairy processing and milk production in the future. Starting in January 2017, the USDA Federal Milk Market Laboratories began reporting lactose content of milk calibration samples as anhydrous lactose and discontinued the reporting of lactose by difference. New, value-added uses for lactose need to be developed. Consistent and accurate methods of lactose measurement and consistent methods of expression of lactose results will support this development process.

\section{ACKNOWLEDGMENTS}

The authors thank the Northeast Dairy Foods Research Center, the Department of Food Science at Cornell University (Ithaca, NY), and the USDA Federal Milk Markets for partial funding of this research. Use of names, names of ingredients, and identification of specific models of equipment is for scientific clarity and does not constitute any endorsement of product by authors, Cornell University, or the Northeast Dairy Foods Research Center. The authors have not stated any conflicts of interest.

\section{REFERENCES}

Abbott, C. W., and M. E. Stiles. 1965. A comparison of the polarimetric and difference methods for the determination of lactose in milk. S. Afr. J. Agric. Sci. 8:303-310.

Agarwal, S., M. Costello, and S. Clark. 2005. Gas-flushed packaging contributes to calcium lactate crystals in cheddar cheese. J. Dairy Sci. 88:3773-3783. https://doi.org/10.3168/jds.S0022 -0302(05)73063-0.

Amamcharla, J. K., and L. E. Metzger. 2011. Development of a rapid method for the measurement of lactose in milk using a blood glucose biosensor. J. Dairy Sci. 94:4800-4809. https://doi.org/10 .3168/jds.2011-4416.

American Dairy Products Institute. 2014. Product Standards. American Dairy Products Institute.

AOAC International. 2016. Official Methods of Analysis. 20th ed. AOAC International.

AOAC International. 2019. New analytical test for lactose in milk. AOAC International. Accessed January 19, 2021. https://www .aoac.org/news/aoac-international-announces-new-analytical-test -for-lactose-in-milk/.

Atra, R., G. Vatai, E. Bekassy-Molnar, and A. Balint. 2005. Investigation of ultra- and nanofiltration for utilization of whey protein and lactose. J. Food Eng. 67:325-332. https://doi.org/10.1016/j .jfoodeng.2004.04.035.

Auldist, M. J., S. Coats, G. L. Rogers, and G. H. McDowell. 1995. Changes in the composition of milk from healthy and mastitic dairy cows during the lactation cycle. Aust. J. Exp. Agric. 35:427436. https://doi.org/10.1071/EA9950427.

Barbano, D. M., and J. L. Clark. 1989. Infrared milk analysis: Challenges for the future. J. Dairy Sci. 72:1627-1636. https://doi.org/ 10.3168/jds.S0022-0302(89)79275-4.

Barbano, D. M., J. L. Clark, C. E. Dunham, and R. J. Fleming. 1990. Kjeldahl method for determination of total nitrogen content of milk: Collaborative study. J. Assoc. Off. Anal. Chem. 73:849-859. https://doi.org/10.1093/jaoac/73.6.849. 
Barbano, D. M., J. M. Lynch, and J. R. Fleming. 1991. Direct and indirect determination of true protein content of milk by Kjeldahl analysis: collaborative study. J. Assoc. Off. Anal. Chem. 74:281288. https://doi.org/10.1093/jaoac/74.2.281.

Berglund, I., G. Pettersson, K. Ostensson, and K. Svennersten-Sjaunja. 2007. Quarter milking for improved detection of increased SCC. Reprod. Domest. Anim. 42:427-432. https://doi.org/10.1111/j .1439-0531.2006.00803.x.

Boehm, G., S. Fanaro, J. Jelinek, B. Stahl, and A. Marini. 2003. Prebiotic concept for infant nutrition. Acta Paediatr. 92:64-67. https: //doi.org/10.1111/j.1651-2227.2003.tb00648.x.

Boehm, G., B. Stahl, J. Jelinek, J. Knol, V. Miniello, and G.E. Moro. 2005. Prebiotic carbohydrates in human milk and formulas. Acta Paediatr. 94:18-21. https://doi.org/10.1111/j.1651-2227.2005 .tb02149.x.

Campbell, M. K., and S. O. Farrell. 2009. Biochemistry. 6th ed. Thomson Higher Education.

Caric, M., and M. Kalab. 1987. Effects of drying techniques on milk powders quality and microstructure: A review. Food Struct. 6:171180.

Cheang, B., and A. L. Zydney. 2004. A two-stage ultrafiltration process for fractionation of whey protein isolate. J. Membr. Sci. 231:159-167. https://doi.org/10.1016/j.memsci.2003.11.014.

Clark, J. L., D. M. Barbano, and C. E. Dunham. 1989. Comparison of two methods for determination of total solids content of milk: Collaborative study. J. Assoc. Off. Anal. Chem. 72:712-718. https: //doi.org/10.1093/jaoac/72.5.712.

Davis, S. R., V. C. Farr, and K. Stelwagen. 1999. Regulation of yield loss and milk composition during once-daily milking: A review. Livest. Prod. Sci. 59:77-94. https://doi.org/10.1016/S0301 -6226(98)00204-8.

de Roode, B. M., M. C. R. Franssen, A. van der Padt, and R. M. Boom. 2003. Perspectives for the industrial enzymatic production of glycosides. Biotechnol. Prog. 19:1391-1402. https://doi.org/10 $.1021 / \mathrm{bp030038q.}$

DeFrain, J. M., A. R. Hippen, K. F. Kalscheur, and D. J. Schingoethe. 2004. Feeding lactose increases ruminal butyrate and plasma $\beta$-hydroxybutyrate in lactating dairy cows. J. Dairy Sci. 87:24862494. https://doi.org/10.3168/jds.S0022-0302(04)73373-1.

DeFrain, J. M., A. R. Hippen, K. F. Kalscheur, and D. J. Schingoethe. 2006. Feeding lactose to increase ruminal butyrate and the metabolic status of transition dairy cows. J. Dairy Sci. 89:267-276. https://doi.org/10.3168/jds.S0022-0302(06)72091-4.

Dincer, T. D. 2000. Mechanisms of Lactose Crystallisation. PhD Thesis. School of Applied Chemistry, Curtin University of Technology.

Dreywood, R. 1946. Qualitative test for carbohydrate material. Ind. Eng. Chem. 18:499. https://doi.org/10.1021/i560156a015.

Dybing, S. T., J. A. Weigand, S. A. Brudvig, E. A. Huang, and R. C. Chandan. 1988. Effect of processing variables on formation of calcium lactate crystals on cheddar cheese. J. Dairy Sci. 71:17011710. https://doi.org/10.3168/jds.S0022-0302(88)79736-2.

Forsbäck, L., H. Lindmark-Månsson, A. Andrén, M. Akerstedt, L. Andrée, and K. Svennersten-Sjaunja. 2010. Day-to-day variation in milk yield and milk composition at the udder-quarter level. J. Dairy Sci. 93:3569-3577. https://doi.org/10.3168/jds.2009-3015.

Fox, P. F. 1997. Advanced Dairy Chemistry: Volume 3: Lactose, Water, Salts and Vitamins. 2nd ed. Chapman and Hall.

Fox, P. F. 2011. Lactose and oligosaccharides | Lactose: Chemistry, properties. Pages 173-181 in Encyclopedia of Dairy Sciences. 2nd ed. Academic Press.

Fox, P. F., T. Uniacke- Lowe, P. L. H. McSweeney, and J. A. O'Mahony. 2015. Dairy Chemistry and Biochemistry. 2nd ed. Springer International Publishing.

Goulden, J. D. S. 1964. Analysis of milk by infra-red absorption. J. Dairy Res. 31:273-284. https://doi.org/10.1017/S0022029900018203.

Gunsel, W. C., and L. Lachman. 1963. Comparative evaluation of tablet formulations prepared from conventionally-processed and spray-dried lactose. J. Pharm. Sci. 52:178-182. https://doi.org/10 $.1002 /$ jps.2600520219.

Haase, G., and T. A. Nickerson. 1966. Kinetic reactions of alpha and beta lactose. I. Mutarotation. J. Dairy Sci. 49:127-132. https://doi .org/10.3168/jds.S0022-0302(66)87811-6.
Haque, K., and Y. H. Roos. 2005. Crystallization and X-ray diffraction of spray-dried and freeze-dried amorphous lactose. Carbohydr. Res. 340:293-301. https://doi.org/10.1016/j.carres.2004.11.026.

Hardwick, D. C., J. L. Linzell, and S. M. Price. 1961. The effect of glucose and acetate on milk secretion by the perfused goat udder. Biochem. J. 80:37-45. https://doi.org/10.1042/bj0800037.

Harris, D. C. 2010. Quantitative Chemical Analysis. 8th ed. W. H. Freeman and Company.

Herrington, B. L. 1934. Some physico-chemical properties of lactose: VI. The solubility of lactose in salt solutions; the isolation of a compound of lactose and calcium chloride. J. Dairy Sci. 17:805814. https://doi.org/10.3168/jds.S0022-0302(34)93306-3.

Hudson, C. S. 1904. The hydration of milk-sugar in solution. J. Am. Chem. Soc. 26:1065-1082. https://doi.org/10.1021/ja01999a002.

Hudson, C. S. 1908. Further studies on the forms of milk sugar. J. Am. Chem. Soc. 30:1767-1783. https://doi.org/10.1021/ja01953a015.

Hunziker, O.F., and B.H. Nissen. 1926. Lactose solubility and lactose crystal formation. I. Lactose solubility. J. Dairy Sci. 9:517-537. https://doi.org/http://dx.doi.org/10.3168/jds.S0022 $-0302(26) 93924-6$

IDF (International Dairy Federation). 2002a. Standard 79-1. Dried milk, dried ice cream mixes, and processed cheese. Determination of lactose content. Part 1. Pages 1-14. International Dairy Federation.

IDF (International Dairy Federation). 2002b. Standard 79-2. Dried milk, dried ice cream mixes, and processed cheese. Determination of lactose content. Part 2. Pages 1-14. International Dairy Federation.

IDF (International Dairy Federation). 2007. International Standard 198: Milk and milk products - Determination of lactose content by high-performance liquid chromatography. International Dairy Federation.

IDF (International Dairy Federation). 2010. International Standard 214: Milk - Determination of lactose content - Enzymatic method using difference in $\mathrm{pH}$. International Dairy Federation.

International Dairy Foods Association. 2016. Dairy Facts 2016 Edition. International Dairy Foods Association.

Jawad, R., A. F. Drake, C. Elleman, G. P. Martin, F. J. Warren, B. B. Perston, P. R. Ellis, M. A. Hassoun, and P. G. Royall. 2014. Stability of sugar solutions: A novel study of the epimerization kinetics of lactose in water. Mol. Pharm. 11:2224-2238. https://doi.org/10 .1021/mp400509t.

Jawad, R., C. Elleman, L. Vermeer, A. F. Drake, B. Woodhead, G. P. Martin, and P. G. Royall. 2012. The measurement of the $\beta / \alpha$ anomer composition within amorphous lactose prepared by spray and freeze drying using a simple (1)H-NMR method. Pharm. Res. 29:511-524. https://doi.org/10.1007/s11095-011-0575-6.

Kaialy, W., A. Alhalaweh, S. P. Velaga, and A. Nokhodchi. 2012. Influence of lactose carrier particle size on the aerosol performance of budesonide from a dry powder inhaler. Powder Technol. 227:7485. https://doi.org/10.1016/j.powtec.2012.03.006.

Kastens, M. L., and F. A. Baldauski. 1952. A staff-industry collaborative report chemicals from milk. Ind. Eng. Chem. 44:1257-1268. https://doi.org/10.1021/ie50510a026.

Kaylegian, K. E., J. M. Lynch, J. R. Fleming, and D. M. Barbano. 2009. Influence of fatty acid chain length and unsaturation on midinfrared milk analysis. J. Dairy Sci. 92:2485-2501. https://doi.org/ 10.3168/jds.2008-1910.

Kleyn, D. H. 1985. Determination of lactose by an enzymatic method. J. Dairy Sci. 68:2791-2798. https://doi.org/10.3168/jds.S0022 $-0302(85) 81167-\mathrm{X}$.

Kvidera, S. K., E. A. Horst, M. Abuajamieh, E. J. Mayorga, M. S. Fernandez, and L. H. Baumgard. 2017. Glucose requirements of an activated immune system in lactating Holstein cows. J. Dairy Sci. 100:2360-2374. https://doi.org/10.3168/jds.2016-12001.

Kyle, R. C., and R. J. Henderson. 1970. Lactose manufacture. Emery Carlton Swanson, assignee. US Pat. No. 3,511,226.

Leitner, G., M. Chaffer, A. Shamay, F. Shapiro, U. Merin, E. Ezra, A. Saran, and N. Silanikove. 2004. Changes in milk composition as affected by subclinical mastitis in sheep. J. Dairy Sci. 87:46-52. https://doi.org/10.3168/jds.S0022-0302(04)73140-9. 
Linzell, J. L., and M. Peaker. 1971. Mechanism of milk secretion. Physiol. Rev. 51:564-597. https://doi.org/10.1152/physrev.1971 .51 .3 .564 .

Liu, H., K. Zhao, and J. Liu. 2013. Effects of glucose availability on expression of the key genes involved in synthesis of milk fat, lactose and glucose metabolism in bovine mammary epithelial cells. PLoS One 8:e66092. https://doi.org/10.1371/journal.pone.0066092.

Luzzana, M., D. Agnellini, P. Cremonesi, and G. Caramenti. 2001. Enzymatic reactions for the determination of sugars in food samples using the differential $\mathrm{pH}$ technique. Analyst 126:2149-2152. https: //doi.org/10.1039/b106880f.

Luzzana, M., D. Agnellini, P. Cremonesi, G. Caramenti, and S. De Vita. 2003. Milk lactose and lactulose determination by the differential pH technique. Lait 83:409-416. https://doi.org/10.1051/ lait:2003022.

Lynch, J. M., D. M. Barbano, and J. R. Fleming. 2007. Determination of the lactose content of fluid milk by spectrophotometric enzymatic analysis using weight additions and path length adjustment: Collaborative study. J. AOAC Int. 90:196-216.

Lynch, J. M., D. M. Barbano, M. Schweisthal, and J. R. Fleming. 2006. Precalibration evaluation procedures for mid-infrared milk analyzers. J. Dairy Sci. 89:2761-2774. https://doi.org/10.3168/jds .S0022-0302(06)72353-0.

Majd, F., and T. A. Nickerson. 1976. Effect of alcohols on lactose solubility. J. Dairy Sci. 59:1025-1032. https://doi.org/10.3168/jds .S0022-0302(76)84319-6.

Maubois, J. L. 1980. Ultrafiltration of whey. Int. J. Dairy Technol. 33:55-58. https://doi.org/10.1111/j.1471-0307.1980.tb01472.x.

Miglior, F., A. Sewalem, J. Jamrozik, J. Bohmanova, D. M. Lefebvre, and R. K. Moore. 2007. Genetic analysis of milk urea nitrogen and lactose and their relationships with other production traits in Canadian Holstein cattle. J. Dairy Sci. 90:2468-2479. https://doi .org/10.3168/jds.2006-487.

Morris, D. L. 1948. Quantitative determination of carbohydrates with Dreywood's anthrone reagent. Science 107:254-255. https://doi .org/10.1126/science.107.2775.254.

Moynihan, A. C., S. Govindasamy-Lucey, M. Molitor, J. J. Jaeggi, M. E. Johnson, P. L. H. McSweeney, and J. A. Lucey. 2016. Effect of standardizing the lactose content of cheesemilk on the properties of low-moisture, part-skim mozzarella cheese. J. Dairy Sci. 99:7791-7802. https://doi.org/10.3168/jds.2016-11215.

Munson, L. S., and P. H. Walker. 1906. The unification of reducing sugar methods. J. Am. Chem. Soc. 28:663-686. https://doi.org/10 $.1021 / \mathrm{ja01972a001.}$

Nezbed, R. L. 1974. Method of treating lactose. Kraftco Corporation, assignee. US Pat. No. 3,802,914.

Nickerson, T. A. 1956. Lactose crystallization in ice cream. II. Factors affecting rate and quantity. J. Dairy Sci. 39:1342-1350. https://doi .org/10.3168/jds.S0022-0302(56)94858-5.

Nickerson, T. A. 1960. Lactose crystallization in ice cream. IV. Factors responsible for reduced incidence of sandiness. J. Dairy Sci. $43: 354-359$.

Nickerson, T. A., and S. G. Lim. 1974. Effect of various alcohols on lactose. J. Dairy Sci. 57:1320-1324. https://doi.org/10.3168/jds .S0022-0302(74)85062-9.

Nickerson, T. A., and E. E. Moore. 1972. Solubility interrelations of lactose and sucrose. J. Food Sci. 37:60-61. https://doi.org/10 $.1111 / j .1365-2621.1972 . t b 03385 . x$

Palmieri, N., M. B. Forleo, and E. Salimei. 2017. Environmental impacts of a dairy cheese chain including whey feeding: An Italian case study. J. Clean. Prod. 140:881-889. https://doi.org/10.1016/ j.jclepro.2016.06.185.

Patel, K. N., and T. A. Nickerson. 1970. Influence of sucrose on the mutarotation velocity of lactose. J. Dairy Sci. 53:1654-1658. https: //doi.org/10.3168/jds.S0022-0302(70)86458-X.

Perry, N. A., and P. F. Doan. 1949. A picric acid method for the simultaneous determination of lactose and sucrose in dairy products. J. Dairy Sci. 33:176-185. https://doi.org/10.3168/jds.S0022 -0302(50)91883-2.

Písecký, J. 1981. Technology of skimmed milk drying. Int. J. Dairy Technol. 34:57-62. https://doi.org/10.1111/j.1471-0307.1981 tb01500.x.
Polavarapu, P. L. 2002. Optical rotation: Recent advances in determining the absolute configuration. Chirality 14:768-781. https:// doi.org/10.1002/chir.10145.

Pollott, G. E. 2004. Deconstructing milk yield and composition during lactation using biologically based lactation models. J. Dairy Sci. 87:2375-2387. https://doi.org/10.3168/jds.S0022-0302(04)73359 $-7$.

Saito, Z. 1985. Particle structure in spray-dried whole milk and instant skim milk powder as related to lactose crystallization. Food Microstruct. 4:333-340.

Scales, F. M. 1915. The determination of reducing sugars: A volumetric method for determining cuprous oxide without removal from Fehling's solution. J. Biol. Chem. 23:81-87. https://doi.org/10 .1016/S0021-9258(18)87603-7.

Seoane, G., H. Moresco, and P. Sansón. 2008. Simple potentiometric determination of reducing sugars. J. Chem. Educ. 85:1091-1093. https://doi.org/10.1021/ed085p1091.

Sharp, P. F. 1943. Stable crystalline anhydrous alpha lactose product and process. Cornell Research Foundation, Inc., assignee. US Pat. No. 2,319,562.

Sharp, P. F., and H. Doob Jr.. 1941. Quantitative determination of alpha and beta lactose in dried milk and dried whey. J. Dairy Sci. 24:589-602. https://doi.org/10.3168/jds.S0022-0302(41)95438-3.

Torres, D. P. M., M. D. P. F. Gonçalves, J. A. Teixeira, and L. R Rodrigues. 2010. Galacto-oligosaccharides: Production, properties, applications, and significance as prebiotics. Compr. Rev. Food Sci. Food Saf. 9:438-454. https://doi.org/10.1111/j.1541-4337.2010 $.00119 . x$.

Tossavainen, O., and J. Sahlstein. 2010. Process for producing a lactose-free milk product. Valio Ltd., assignee. US Pat. No. 7,829,130 B2.

Troy, H. C., and P. F. Sharp. 1930. $\alpha$ and $\beta$ lactose in some milk products. J. Dairy Sci. 13:140-157. https://doi.org/10.3168/jds.S0022 -0302(30)93513-8.

US Dairy Export Council. 2019. Historical data. Accessed Jan. 19, 2021. https://www.usdec.org/research-and-data/market-information/us -export-data/historical-data.

Westhoff, G. M., B. F. M. Kuster, M. C. Helsinga, H. Pluim, and M. Verhage. 2000. Lactose and Derivatives. Pages 1-9 in Ullmann's Encyclopedia of Industrial Chemistry. Wiley-VCH. https://doi .org/10.1002/14356007.a15_107.pub2.

Whitaker, R. 1933. Some factors influencing the crystallization of lactose in ice cream. J. Dairy Sci. 16:177-202. https://doi.org/10 .3168/jds.S0022-0302(33)93332-9.

Whittier, E. O. 1944. Lactose and its utilization: A review. J. Dairy Sci. 27:505-537. https://doi.org/10.3168/jds.S0022-0302(44)92629 $-9$.

van Scheppingen, W. B., P. H. van Hilten, M. P. Vijverberg, and A. L. L. Duchateau. 2017. Selective and sensitive determination of lactose in low-lactose dairy products with HPAEC-PAD. J. Chromatogr. B Analyt. Technol. Biomed. Life Sci. 1060:395-399. https: //doi.org/10.1016/j.jchromb.2017.06.024.

Wojciechowski, K. L., C. Melilli, and D. M. Barbano. 2016. A proficiency test system to improve performance of milk analysis methods and produce reference values for component calibration samples for infrared milk analysis. J. Dairy Sci. 99:6808-6827. https:/ /doi.org/10.3168/jds.2016-10936.

Wong, N. P. 1988. Fundamentals of Dairy Chemistry. 3rd ed. Van Nostrand Reinhold Company Inc. https://doi.org/10.1007/978-1 -4615-7050-9.

Yang, S. T., and E. M. Silva. 1995. Novel products and new technologies for use of a familiar carbohydrate, milk lactose. J. Dairy Sci. 78:2541-2562. https://doi.org/10.3168/jds.S0022-0302(95)76884 -9 .

Zadow, J. G. 1984. Lactose: Properties and uses. J. Dairy Sci. 67:26542679. https://doi.org/10.3168/jds.S0022-0302(84)81625-2.

\section{ORCIDS}

Matilde Portnoy 으 https://orcid.org/0000-0002-8448-5855 David M. Barbano 다 https://orcid.org/0000-0002-0206-7028 